DOI: https://doi.org/10.24127/ajpm.v10i4.4401

\title{
HUBUNGAN PENGGUNAAN SMARTPHONE DAN KESIAPAN BELAJAR DENGAN HASIL BELAJAR MATEMATIKA
}

\author{
Nelly Astuti ${ }^{1}$, Muncarno ${ }^{2}$, Diah Mirantika ${ }^{3}$, Victor Dinnata $^{4}$ \\ ${ }^{1,2}$ Universitas Lampung \\ *Corresponding author. \\ E-mail: $\quad$ nelly.astuti@fkip.unila.ac.id ${ }^{1)}$ \\ $\underline{\text { muncarno.muncar@gmail.com }}^{2)}$
}

Received 04 November 2021; Received in revised form 08 December 2021; Accepted 28 December 2021

\begin{abstract}
Abstrak
Masalah mendasar dalam penelitian ini adalah rendahnya hasil belajar matematika. Berangkat dari masalah tersebut perlu dilakukan kajian mendalam terkait hal-hal yang memiliki hubungan dengan masalah. Dua hal yang dianggap memiliki hubungan dengan rendahnya hasil belajar matematika peserta didik adalah penggunaan smartphone dan kesiapan belajar. Tujuan penelitian ini adalah untuk menganalisis hubungan antara penggunaan smartphone dan kesiapan belajar dengan hasil belajar matematika. Jenis penelitian ex-postfacto korelasi. Subjek dari penelitian adalah peserta didik kelas V SD Negeri Gugus Wahidin Sudiro Husodo, dengan populasi berjumlah 118 dan sampel berjumlah 54. Instrumen pengumpul data berupa angket dengan skala likert, yang sebelumnya diuji validitas dan reliabilitasnya. Analisis data yang digunakan adalah korelasi product moment dan multiple correlation. Hasil penelitian menunjukkan bahwa koofisien korelasi antara penggunaan smartphone dan kesiapan belajar dengan hasil belajar adalah sebesar 0,515 bertanda positif dengan kriteria cukup kuat. Selanjutnya kontribusi variabel $\mathrm{X}_{1}$ dan $\mathrm{X}_{2}$ dengan $\mathrm{Y}$ sebesar $26,52 \%$. Hal itu berarti penggunaan smartphone dan kesiapan belajar secara bersama-sama memberi pengaruh sebesar 26,52\% terhadap hasil belajar matematika. Penggunaan smartphone dan kesiapan belajar menjadi variabel yang perlu diperhatikan untuk mencapai pembelajaran daring yang dapat memfasilitasi peserta didik untuk memperoleh hasil belajar yang baik.
\end{abstract}

Kata kunci: Hasil belajar matematika; kesiapan belajar; penggunaan smartphone.

\begin{abstract}
The basic problem on this research is outcomes of mathematics learning getting low. Based on this problem, there in an analysis to analyze the reason of this problem. The purpose of this study was to determine the significant relationship between using smartphone variable and learning readiness with mathematics learning outcomes. The type of this research was ex-postfacto correlation. The subject of this research are fifth grade students in Wahidin Sudiro Husodo area. The population was 118 students and the research sample was 54 students. The data collection instrument was a questionnaire with ascale likert, which had previously been tested for validity and reliability. The data analysis used the product moment and multiple correlation. The results showed that there were a significant relationship betweenuse smartphone and learning readiness to mathematics learning outcomes with a correlation coefficient of 0,515. The contribution of the two variables (using smartphone and learning readiness) to learning outcames are 26,52\%. Using smartphone and learning readiness become an important variable to increase mathematics elarning outcomes.
\end{abstract}

Keywords: Learning readiness; mathematics learning outcomes; smartphone using.

This is an open access article under the Creative Commons Attribution 4.0 International License 
DOI: https://doi.org/10.24127/ajpm.v10i4.4401

\section{PENDAHULUAN}

Pandemi Covid-19 terjadi di Indonesia sejak tahun 2020. Hadirnya pandemi covid-19 telah merubah tatanan hidup masyarakat Indonesia termasuk pada sektor pendidikan. Pembelajaran yang semula dilaksanakan secara tatap muka harus diubah menjadi pembelajaran dalam jaringan atau daring ( (Anugrahana, 2020), (Dong, Cao, \& Lia, 2020), (Mahitsa \& Mahardini, 2020), dan (Mishra, Gupta, \& Shree, 2020). Pembelajaran daring dilaksanakan untuk semua mata pelajaran termasuk matematika.

Pembelajaran matematika secara daring tidak dapat dilakukan secara maksimal. Hasilnya, hasil belajar matematika peserta didik rendah. Terlebih pada jenjang sekolah dasar, dimana peserta didik belum mampu mengatur dan menyesuaikan dirinya dalam mengikuti pembelajaran daring. Sebagian besar siswa terkendala dalam mengikuti pembelajaran daring khususnya dalam hal motivasi belajar (Sapti, Rakhmah, \& Pangestika, 2021). Akibatnya, terjadi penurunan hasil belajar.

Pembelajaran daring didominasi oleh penggunaan media digital yang salah satunya adalah smartphone. Penggunaan smartphone saat ini tidak hanya di kalangan orang dewasa saja, melainkan dikalangan anak-anak tentunya sudah tidak asing lagi dengan penggunaan smartphone (Ramadhani, 2020). Penggunaan smartphone dalam pembelajaran sejatinya bukanlah hal baru. Akan tetapi, menggunakan smartphone secara dominan dalam pembelajaran di sekolah adalah suatu hal baru. Meskipun penggunaan smartphone secara dominan dalam pembelajaran didorong karena situasi dan kondisi yang mendesak, namun penggunaan smartphone ternyata juga memberikan dampak negatif terhadap peserta didik SD. Penggunaan smartphone lebih dari tiga jam sehari cenderung malas belajar, tidak memperhatikan pelajaran, dan menyukai cara-cara yang instan dalam menyelesaikan masalah yang berakibat pada penurunan hasil belajar (Satrianawati, 2017). Selain itu, penggunaan smartphone secara berlebihan merubah kebiasaan belajar dan kesulitan untuk mengontrolnya (Kim, Lee, \& Choi, 2015).

Hal lain yang juga harus diperhatikan dalam perubahan proses belajar adalah kesiapan belajar peserta didik maupun orang tua yang berkewajiban dalam melakukan pendampingan belajar. masalah pembelajaran daring adalah ketidaksiapan peserta didik dan orang tua dalam menghadapi pembelajaran online, pembelajaran online tidak mempunyai suasana formal seperti pembelajaran yang dilakukan di sekolah, pada pembelajaran online tidak terjadi interaksi sosial sesama peserta didik (Dong, Cao, \& Lia, 2020). Kesiapan belajar akan membuat peserta didik lebih termotivasi untuk meningktkan dan memaksimalkan prestasi belajar (Harmini, 2017).

Penggunaan smartphone dalam pembelajaran serta kesiapan belajar peserta didik SD menjadi dua hal yang menunjukkan pengaruh terhadap keberhasilan pembelajaran daring. Berdasarkan hasil observasi, kesiapan belajar peserta didik SD dengan menggunakan perangkat smartphone belum baik. ditemukan peserta didik yang sedang bermain game online setelah mereka mengumpulkan tugas sekolah. Selain itu, telah dilakukan wawancara dengan pendidik SD, menurut penuturan pendidik, bahwasannya peserta didik belum 
memiliki kesiapan belajar dengan menggunakan media smartphone, hal ini terjadi karena peserta didik lebih banyak menggunakan waktu untuk bermain game dengan smartphone dibandingkan belajar, sehingga berpengaruh terhadap ketidaktercapaian materi pelajaran yang berdampak pada kesulitan dalam penguasaan materi terutama mata pelajaran matematika.

Penelitian-penelitian sebelumnya telah membahas bahwa penggunaan smartphone dalam pembelajaran berpengaruh terhadap hasil belajar ((Rozalia, 2017) dan (Naibaho \& Wulandari, 2021)). Begitu pula dengan kesiapan belajar peserta didik dalam pembelajaran daring juga berpengaruh terhadap hasil belajar (Putri, 2019). Akan tetapi, belum ada penelitian yang menganalisis hubungan keduanya secara bersamaan terhadap hasil belajar matematika. Oleh karena itu, tujuan dari penelitian ini adalah untuk menganalisis hubungan antara penggunaan smartphone dan kesiapan belajar dengan hasil belajar matematika peserta didik SD.

\section{METODE PENELITIAN}

Penelitian ini menggunakan pendekatan kuantitatif. Jenis penelitian yang digunakan adalah ex-post facto korelasional. Penelitian dilaksanakan di SD Negeri Gugus Wahidin Sudiro Husodo yang terdiri dari SD Negeri 2 Metro Barat, SD Negeri 3 Metro Barat, SD Negeri 4 Metro Barat, SD Negeri 5 Metro Barat. Waktu penelitian dilaksanakan pada semester genap tahun pelajaran 2020/2021.

Populasi penelitian ini adalah peserta didik kelas V SD Negeri Gugus Wahidin Sudiro Husodo yang berjumlah 118 peserta didik. Penelitian ini menggunakan teknik probability sampling yaitu proposionate stratified random sampling karena pengambilan sampel dilakukan secara acak dengan memperhatikan strata yang ada dalam populasi, dan diperoleh sampel sebanyak 54 peserta didik.

Prosedur penelitian ini sebagai berikut: (1) Memilih subjek penelitian yaitu peserta didik kelas V SD Negeri Gugus Wahidin Sudiro Husodo Metro Barat ; (2) Menyusun kisi-kisi dan instrumen pengumpul data yang berupa angket; (3) Menguji coba instrumen pengumpul data pada subjek uji coba instrumen; (4) Menganalisis data dari hasil uji coba instrumen untuk mengetahui apakah instrumen yang disusun telah valid dan reliabel; (5) Melaksanakan penelitian dengan membagikan instrumen berupa angket kepada sampel penelitian. Adapun untuk mengetahui hasil belajar matematika peserta didik dilakukan studi dokumentasi yang dilihat pada Penilaian Tengah Semester (PTS) kelas V SD Negeri Gugus Wahidin Sudiro Husodo Metro Barat; (6) Menghitung data yang diperoleh untuk mengetahui hubungan dan tingkat keterkaitan penggunaan smartphone dan kesiapan belajar dengan hasil belajar matematika peserta didik kelas V SD Negeri Gugus Wahidin Sudiro Husodo Metro Barat; (7) Interpretasi hasil perhitungan data.

Teknik Pengumpulan data dalam penelitian ini adalah sebagai berikut: (1) Observasi, dilakukan untuk memperoleh data tentang kondisi sekolah atau deskripsi tentang lokasi penelitian yang akan dilaksanakan di kelas V SD Negeri Gugus Wahidin Sudiro Husodo Metro Barat; (2) Wawancara, dilakukan terhadap pendidik kelas V SD Negeri Gugus Wahidin Sudiro Husodo Metro Barat untuk memperoleh informasi mengenai penggunaan smartphone dan kesiapan belajar; (3) Studi dokumentasi, digunakan untuk 
memperoleh data tentang hasil belajar peserta didik berupa nilai ulangan semester ganjil tahun pelajaran 2020/2021 serta data lain yang menunjang penelitian; (4) Angket kepada peserta didik untuk memperoleh informasi mengenai penggunaan smartphone dan kesiapan belajar.

Pengukuran angket berpedoman pada skala Likert dengan empat alternatif jawaban tanpa jawaban netral untuk menghindari jawaban ragu-ragu dan tidak mempunyai jawaban yang jelas. Angket diuji coba sebelum digunakan dalam penelitian. Pengujian validitas angket menggunakan rumus korelasi product moment. Uji reliabilitas angket menggunakan rumus korelasi alpha cronbach.

Teknik analisis data menggunakan analisis kuantitatif. Uji prasyarat analisis berupa uji normalitas dilakukan menggunakan rumus chi kuadrat dan untuk uji prasyarat liniearitas menggunakan uji-F. Pengujian hipotesis menggunakan product moment dan multiple correlation dengan kriteria pengambilan keputusan, yaitu jika $t_{\text {hitung }}$ $>t_{\text {tabel }}$ maka Ha diterima. Apabila Ha diterima berarti hipotesis yang diajukan dapat diterima artinya terdapat hubungan yang signifikan antara penggunaan smartphone dan kesiapan belajar dengan hasil belajar matematika.

\section{HASIL DAN PEMBAHASAN}

Setelah dilaksanakan pengambilan data, diperoleh beberapa hasil. Hasil yang pertama adalah hasil angket yang diberikan kepada peserta didik kelas V SD Negeri Gugus Wahidin Sudiro Husodo Kecamatan Metro Barat. Kedua, hasil belajar matematika peserta didik yang diperoleh dari nilai PTS semester ganjil. Data yang diperoleh dapat dilihat pada Tabel 1, dimana variabel $\mathrm{X} 1$ adalah penggunaan smartphone, variabel $\mathrm{X} 2$ adalah kesiapan belajar, dan variabel $\mathrm{Y}$ adalah hasil belajar.

Tabel 1. Data variabel $\mathrm{X}_{1}, \mathrm{X}_{2}$, dan $\mathrm{Y}$

\begin{tabular}{cccc}
\hline \multirow{2}{*}{ Data } & \multicolumn{3}{c}{ Variabel } \\
\cline { 2 - 4 } & $\mathbf{X}_{\mathbf{1}}$ & $\mathbf{X}_{\mathbf{2}}$ & $\mathbf{Y}$ \\
\hline $\mathrm{N}$ & 54 & 54 & 54 \\
Skor Terbesar & 49 & 51 & 69 \\
Skor Terkecil & 96 & 90 & 90 \\
Median & 75 & 73 & 69,5 \\
Modus & 75 & 73 & 70 \\
$\sum$ & 3900 & 3942 & 4276 \\
Rerata & 72,35 & 72,63 & 78,78 \\
Simpangan Baku & 11,24 & 9,83 & 5,21 \\
\hline
\end{tabular}

Berdasarkan Tabel 1 dapat diketahui bahwa data variabel $\mathrm{X}_{1}$ dominan dibandingkan dengan variabel $\mathrm{X}_{2}$ Hal tersebut dapat dilihat dari $\mathrm{S}$ (simpangan baku) kedua variabel tersebut, variabel $X_{1}>$ variabel $X_{2}$. Lebih lanjut, data hasil belajar kemudian disusun dalam bentuk distribusi frekuensi seperti yang disajikan pada Tabel 2.

Tabel 2. Distribusi hasil belajar matematika

\begin{tabular}{cccc}
\hline No & $\begin{array}{c}\text { Kelas } \\
\text { Interval }\end{array}$ & Frekuensi & $\begin{array}{c}\text { Persentase } \\
(\mathbf{\%})\end{array}$ \\
\hline 1 & $59-61$ & 5 & 9,3 \\
2 & $62-64$ & 7 & 12,9 \\
3 & $65-67$ & 10 & 18,5 \\
4 & $68-70$ & 13 & 24,1 \\
5 & $71-73$ & 8 & 14,8 \\
6 & $74-76$ & 6 & 11,1 \\
7 & $77-80$ & 5 & 9,3 \\
\hline Jumlah & $\mathbf{5 4}$ & $\mathbf{1 0 0}$ \\
\hline
\end{tabular}

Berdasarkan data pada Tabel 2, terlihat bahwa sebanyak $80,6 \%$ peserta didik masih memperoleh hasil di bawah KKM yang ditetapkan yaitu 75. Adapun sebanyak 20,4 \%. peserta didik memperoleh hasil di atas KKM yang ditetapkan. Hal ini menunjukkan bahwa hasil belajar matematika peserta didik masih perlu ditingkatkan lagi. Selain data pada Tabel 2, disajikan pula data 
DOI: https://doi.org/10.24127/ajpm.v10i4.4401

hasil pengisian angket penggunaan smartphone yang dapat dilihat pada Tabel 3.

Tabel 3. Data penggunaan smartphone

\begin{tabular}{cccc}
\hline No & $\begin{array}{c}\text { Kelas } \\
\text { Interval }\end{array}$ & Frekuensi & $\begin{array}{c}\text { Persentase } \\
(\boldsymbol{\%})\end{array}$ \\
\hline 1 & $49-55$ & 5 & 9,3 \\
2 & $56-62$ & 6 & 11,1 \\
3 & $63-69$ & 9 & 16,7 \\
4 & $70-76$ & 14 & 25,9 \\
5 & $77-83$ & 12 & 22,2 \\
6 & $84-90$ & 5 & 9,3 \\
7. & $91-96$ & 3 & 5,5 \\
\hline \multicolumn{2}{c}{ Jumlah } & $\mathbf{5 4}$ & $\mathbf{1 0 0}$
\end{tabular}

Tabel 3 menunjukan bahwa distribusi frekeuensi tertinggi berada pada interval 70-76 sebanyak 14 peserta didik, adapun kelas interval tertinggi yaitu 91-96 frekuennsinya hanya mencapai 3 peserta didik. Hal tersebut menunjukan bahwa penggunaan smartphone oleh peserta didik harus lebih bijak dalam memanfaatkan penggunaan smartphone. Data kesiapan belajar peserta didik dapat dilihat pada Tabel 4.

Tabel 4. Data kesiapan belajar

\begin{tabular}{cccc}
\hline No & $\begin{array}{c}\text { Kelas } \\
\text { Interval }\end{array}$ & Frekuensi & $\begin{array}{c}\text { Persentase } \\
(\boldsymbol{\%})\end{array}$ \\
\hline 1 & $51-56$ & 4 & 7,4 \\
2 & $57-62$ & 5 & 9,3 \\
3 & $63-68$ & 8 & 14,8 \\
4 & $69-74$ & 13 & 24,1 \\
5 & $75-80$ & 12 & 22,2 \\
6 & $81-86$ & 7 & 12,9 \\
7 & $87-90$ & 5 & 9,3 \\
\hline \multicolumn{2}{c}{ Jumlah } & $\mathbf{5 4}$ & $\mathbf{1 0 0}$ \\
\hline
\end{tabular}

Tabel 4 menunjukan bahwa kesiapan belajar harus lebih ditingkatkan lagi. Distribusi frekuensi tertinggi berada pada interval 69-74 sebanyak 13 peserta didik, sedangkan kelas interval tertinggi yaitu 87-90 frekeunsinya hanya 5 peserta didik.
Data hasil belajar matematika, penggunaan smartphone, kesiapan belajar di atas perlu dilakukan uji prasyarat, yaitu uji normalitas dan linieritas. Hasil perhitungan uji normalitas menggunakan rumus chi kuadrat, menunjukkan hasil belajar matematika $(\mathrm{Y})$ diperoleh $\chi^{2}$ hitung $=$ 4,904 dan $\chi^{2}$ tabel $=12,592$ sehingga $\chi^{2}$ hitung $=4,904<\chi^{2}$ tabel $=12,592$, artinya data variabel (Y) berdistribusi normal. Hasil perhitungan uji normalitas penggunaan smartphone $\left(\mathrm{X}_{1}\right)$ diperoleh data $\chi^{2}$ hitung $=3,478$ dan $\chi^{2}$ tabel $=12,592$ sehingga $\chi^{2}$ hitung $=3,478<\chi^{2}$ tabel $=12,592$, artinya data variabel $\mathrm{X}_{1}$ berdistribusi normal. Hasil perhitungan uji normalitas kesiapan belajar $\left(\mathrm{X}_{2}\right)$ diperoleh data $\chi^{2}$ hitung $=$ 5,016 dan $\chi^{2}$ tabel $=12,592$ sehingga $\chi^{2}$ hitung $=5,016<\chi^{2}$ tabel $=12,592$, artinya data variabel $\left(\mathrm{X}_{2}\right)$ berdistribusi normal.

Hasil uji linieritas penggunaan smartphone $\left(\mathrm{X}_{1}\right)$ dengan hasil belajar (Y) menggunakan rumus Uji-F diperoleh $\mathrm{F}_{\text {hitung }}=0,83$ dan $\mathrm{F}_{\text {tabel }}=1,96$. Sesuai dengan kaidah yang menyatakan bahwa $F_{\text {hitung }}=0,83 \leq F_{\text {tabel }} 1,96$ hal ini berarti data berpola linier. Hasil uji linieritas variabel $\left(\mathrm{X}_{2}\right)$ dan $(\mathrm{Y})$ diperoleh $\mathrm{F}_{\text {hitung }}=0,63$ dan $\mathrm{F}_{\text {tabel }}=1,91$. Sesuai dengan kaidah yang menyatakan bahwa $F_{\text {hitung }}=0,63 \leq \mathrm{F}_{\text {tabel }} 1,91$ hal ini berarti data berpola linier.

Setelah dilakukan uji prasyarat, kemudian dilanjutkan dengan uji korelasi. Hasil uji yang pertama berkenaan dengan variabel penggunaan smartphone dan kesiapan belajar. Hasil dari koefisien korelasi antara variabel $\mathrm{X}_{1}$ (penggunaan smartphone) dengan variabel $\mathrm{X}_{2}$ (kesiapan belajar) sebesar 0,418 dengan kriteria cukup kuat. Selanjutnya kontribusi variabel $\mathrm{X}_{1}$ terhadap variabel $\mathrm{X}_{2}$ sebesar $17,51 \%$. Hal ini berarti penggunaan smartphone 
DOI: https://doi.org/10.24127/ajpm.v10i4.4401

memiliki hubungan sebesar 17,51\% terhadap kesiapan belajar. Artinya terdapat hubungan yang signifikan antara penggunaan smartphone dengan kesiapan belajar.

Smartphone adalah sebuah device (alat) yang memungkinkan untuk melakukan komunikasi yang di dalamnya terdapat fungsi PDA (Personal Digital Assistant) dan berkemampuan seperti komputer (Mandias, 2017). Pemanfaatan smartphone sebagai media pembelajaran diperlukan kesiapan belajar dalam menggunakannya, agar materi yang disampaikan dalam proses pembelajaran berjalan dapat diterima secara optimal. kesiapan belajar ialah kondisi awal peserta didik dalam kegiatan belajar untuk menghindari berbagai kesulitan dan dapat mengikuti proses pembelajarn tanpa adanya gangguan (Ma'shumah \& Muhsin, 2019).

Hasil uji kedua menunjukkan koofisien korelasi antara variabel $\mathrm{X}_{1}$ (penggunaan smartphone) dengan $\mathrm{Y}$ (hasil belajar matematika) sebesar 0,449 dengan kriteria cukup kuat. Selanjutnya kontribusi $\mathrm{X}_{1}$ dan variabel $\mathrm{Y}$ sebesar 20,19\%. Hal ini berarti penggunaan smartphone memiliki hubungan sebesar $20,19 \%$ terhadap hasil belajar matematika. Artinya terdapat hubungan yang signifikan antara penggunakan smartphone dengan hasil belajar matematika.

Menurut (Iswidharmanjaya \& Agency, 2014) dampak positif penggunaan smartphone apabila digunakan secara bijak adalah merangsang anak untuk mengikuti perkembangan teknologi, meningkatkan kemampuan berbahasa, mendukug keterampilan akademik, mengurangi stress, dan mengasah keterampilan matematis. Selain berdampak positif, penggunaan smartphone juga mempunyai dampak negatif. Dampak negatif yang timbul dari penggunaan smartphone tersebut adalah hilangnya konsentrasi belajar peserta didik yang membuat hasil belajar peserta didik menurun (Sari, 2019). Penelitian ini relevan dengan penelitian (Harahap, Elly, \& Safiah, 2018) hasil penelitian menunjukkan terdapat hubungan antara pengguanaan smartphone dengan hasil belajar peserta didik kelas V SD.

Hasil uji ketiga menunjukkan koofisien korelasi antara variabel $\mathrm{X}_{2}$ (kesiapan belajar) dengan $\mathrm{Y}$ (hasil belajar) sebesar 0,417 dengan kriteria cukup kuat. Selanjutnya kontribusi $\mathrm{X}_{2}$ (kesiapan belajar) dan variabel Y (hasil belajar matematika) sebesar $17,36 \%$. Hal itu berarti kesiapan belajar memiliki hubungan sebesar 17,36\% terhadap hasil belajar matematika. Artinya terdapat hubungan yang signifikan antara kesiapan belajar dengan hasil belajar matematika. Hal ini relevan dengan penelitian yang dilakukan oleh (Putri, 2019) yang menunjukan adanya hubungan yang positif dan signifikan antara kesiapan belajar dengan hasil belajar matematika. Kesiapan belajar memberikan pengaruh yang cukup besar terhadap hasil belajar yang diperoleh peserta didik (Harmini, 2017).

Hasil uji keempat menunjukan koofisien korelasi sebesar 0,515 bertanda positif dengan kriteria cukup kuat. Selanjutnya kontribusi variabel $\mathrm{X}_{1}$ dan $\mathrm{X}_{2}$ dengan $\mathrm{Y}$ sebesar 26,52\%. Hal itu berarti penggunaan smartphone dan kesiapan belajar secara bersama-sama memberi pengaruh sebesar 26,52\% terhadap hasil belajar matematika. Adapun 73,48\% dipengaruhi oleh faktor lain yang tidak diteliti. Hasil ini relevan juga dengan hasil penelitian yang dilakukan (Rozalia, 2017) yang menunjukkan adanya hubungan negatif 
yang tidak signifikan antara intensitas pemanfaatan gadget dengan prestasi belajar siswa. Intensitas pemanfaatan gadget tidak berpengaruh pada prestasi belajar siswa. Namun, jika dilihat dari tanda negatif pada $r$ hitung, jika semakin tinggi intensitas pemanfaatan gadget maka prestasi siswa dapat menurun. Selanjutnya penelitian (Naibaho \& Wulandari, 2021) yang menyatakan bahwa intensitas pemakaian gadget berpengaruh negatif terhadap hasil belajar matematika, dengan makna semakin tinggi siswa dalam menggunakan gadgetnya tentu akan berdampak pada penurunan nilainya, terutama dalam pelajaran matematika. Hasil penelitian lain dari (Putri, 2019) menunjukan adanya hubungan yang positif dan signifikan antara kesiapan belajar dengan hasil belajar matematika.

\section{KESIMPULAN DAN SARAN}

Berdasarkan hasil penelitian yang telah disajikan, dapat disimpulkan bahwa terdapat hubungan yang signifikan antara penggunaan smartphone dan kesiapan belajar dengan hasil belajar matematika. Penggunaan smartphone dan kesiapan belajar menjadi variabel yang perlu diperhatikan untuk mencapai pembelajaran daring yang dapat memfasilitasi peserta didik untuk memperoleh hasil belajar yang baik.

Berdasarkan kesimpulan maka saran dan rekomendasi bagi peneliti lanjutan agar lebih mengembangkan variabel, populasi dengan subjek penelitian yang lebih luas, dan dapat melakukan penyempurnaan pada indikator-indikator variabel untuk dikembangkan pada instrumen penelitian serta melakukan penelitian sejenis dengan permasalahan yang belum terungkap melalui variabel lain.

\section{DAFTAR PUSTAKA}

Anugrahana, A. (2020). Hambatan , Solusi dan Harapan : Pembelajaran Daring Selama Masa Pandemi Covid-19 Oleh Guru Sekolah Dasar. Scholaria: Jurnal Pendidikan Dan Kebudayaan, 10(3), 282-289.

Dong, C., Cao, S., \& Lia, H. (2020). Young children's online learning during COVID-19 pandemic: Chinese parents' beliefs and attitudes. Children and Youth Services Review, 118(June), 105440.

Harahap, R. S., Elly, R., \& Safiah, I. (2018). Pengaruh Penggunaan Gadget terhadap Hasil Belajar Siswa Kelas V SD Negeri 12 Banda Aceh. Jurnal Ilmiah Pendidikan Guru Sekolah Dasar KIP Unsyiah, 3(1), 119-126.

Harmini, T. (2017). Pengaruh Kesiapan Belajar Terhadap Prestasi Belajar Mahasiswa Pada Pembelajaran Kalkulus. Mathline, 2(2), 145-158.

Iswidharmanjaya, D., \& Agency, B. (2014). Bila Si Kecil Bermain Gadget. Yogyakarta: Bisakimia.

Kim, R., Lee, K.-J., \& Choi, Y.-J. (2015). Mobile Phone Overuse Among Elementary School Students in Korea. Journal of Addictions Nursing, 26(2), 8185.

Ma'shumah, F., \& Muhsin. (2019). Pengaruh Motivasi Belajar, Disiplin Belajar, Cara Belajar dan Interaksi Teman Sebaya terhadap Kesiapan Belajar. Jurnal Pendidikan Ekonomi, 8(1), 318-332.

Mahitsa, M., \& Mahardini, A. (2020). Analisis Situasi Penggunaan Google Classroom pada Pembelajaran Daring Fisika. 
DOI: https://doi.org/10.24127/ajpm.v10i4.4401

Jurnal Pendidikan FIsika, VIII(2), 215-224.

Mandias, G. F. (2017). Analisis Pengaruh Pemanfaatan Smartphone terhadap Prestasi Akademik Mahasiswa Fakultas Komputer Universitas Klabat. Cogito Smart Journal, 3(1), 8390.

Mishra, L., Gupta, T., \& Shree, A. (2020). Online teaching-learning in higher education during lockdown period of COVID-19 pandemic. International Journal of Educational Research Open, June, 100012.

Naibaho, C. D., \& Wulandari, I. G. (2021). Kontribusi Intensitas Pemakaian Gadget dan Peran Orang Tua terhadap Hasil Belajar Matematika Siswa Kelas V SD . Jurnal Pedagogi dan Pembelajaran, 4(1), 59-68.

Putri, A. E. (2019). Hubungan Kesiapan Belajar Siswa dan Bimbingan Belajar Orang Tua dengan Hasil Belajar Matematika Kelas V SDN Gugus Muhammad Syafi'i Margorejo Pati. Skripsi, Universitas Negeri Semarang: Semarang.

Ramadhani. (2020). Efek Penggunaan Smartphone Berkelanjutan pada Masa Pandemi COVID-19 terhadap Perilaku Anak. Jurnal Amal Pendidikan, 1: 96-105.

Rozalia, M. F. (2017). Hubungan Intensitas Pemanfaatan Gadget dengan Prestasi Belajar Siswa Kelas V Sekolah Dasar. Jurnal Pemikiran dan Pengembangan SD, 5(2), 722-731.

Sapti, M., Rakhmah, B., \& Pangestika, R. R. (2021). Deskripsi Kendala Pembelajaran Daring Melalui Whatsapp Pada Mata Pelajaran Matematika di Sekolah Dasar.
Jurnal Basicedu, 5(5), 37383746.

Sari, E. M. (2019). Pengaruh Penggunaan Smartphone terhadap Minat dan Hasil Belajar Siswa SMK Swasta Bina Taruna 2 Medan Tahun Pelajaran 2018/2019. (Skripsi), Universitas Muhammadiyah Sumatera Utara: Medan.

Satrianawati. (2017). Dampak Penggunaan Handphone terhadap Aktivitas Belajar Siswa Sekolah Dasar. Jurnal Profesi Pendidikan Dasar, 4(1), 54-61. 